\title{
Dermatoglyphic patterns in dementia of the Alzheimer type: a case-control study
}

Claudine Berr, Nicole Okra-Podrabinek, Dorin Feteanu, Sophie Taurand, Marie-Pierre Hervy, Françoise Forette, François Piette, Renée Sebag-Lanoe, Annick Alperovitch

\begin{abstract}
Study objective-The aim was to compare digital and palmar dermatoglyphics in subjects with dementia of Alzheimer type and in mentally healthy elderly controls.

Design-This design was a case-control study.

Setting-The study was carried out in geriatric units and retirement communities in the Paris area.

Participants-Cases were women with clinically diagnosed Alzheimer type dementia according to DSM III-R criteria $(\mathbf{n}=82)$, mainly with late onset of the disease. Controls were women aged 85 years or older without cognitive deterioration $(n=76)$.
\end{abstract}

Measurements and main results-Finger and palm prints obtained from both hands by the classical ink method were examined. Fingerprints were classified into four types of figures. On palms, palmar flexion creases, palmar axial triradii, true patterns of the hypothenar area, and main line terminations were described. Examinations were performed by two examiners blind to the subjects's diagnostic category. For the different patterns studied, no major differences between dementia patients and elderly controls were found. Nor was there evidence of high frequencies of features commonly observed in Down's syndrome (trisomy 21), which have previously, though sporadically, been reported.

Conclusions-On one of the largest samples of Alzheimer dementia patients studied, and with evaluation blind to diagnosis, no evidence has been found that particular dermatoglyphic patterns occur like those observed in Down's syndrome, a disease which is related to dementia of the Alzheimer type.

f Epidemiol Community Health 1992; 46: 512-516

Dementia of the Alzheimer type is now recognised as the major cause of dementia in the elderly, but little is known about its aetiology. ${ }^{1-3}$ It has been proposed that a genetic mechanism related to chromosome 21 is involved. ${ }^{4}$

Down's syndrome is related to triplication of all or part of chromosome 21. Intriguing relationships between Down's syndrome and Alzheimer dementia have prompted an accelerated search for a genetic base for Alzheimer's disease. ${ }^{5}$ Neuropathology has given us important evidence in this field, indicating similarities between Alzheimer dementia and Down's syndrome. Adults with
Down's syndrome tend to show Alzheimer type changes in their brains by the age of $30 .^{67}$ Both senile plaques and neurofibrillary tangles are ultrastructurally identical in the two disorders, as is the $\beta$ amyloid deposited in the senile plaques. However, the existence of clinical Alzheimer dementia has not been well documented in mentally retarded adults with Down's syndrome. ${ }^{8}$ The gene of $\beta$ amyloid protein, which is the major component of Alzheimer lesions, has been located on chromosome 21. A mutation within the amyloid precursor protein has been reported as the possible cause of Alzheimer dementia in two families in which the disease was apparently inherited as an autosomal dominant disorder. ${ }^{9}$ In addition to this protein, segregation of different restriction fragment polymorphisms from this chromosome is currently being studied in families with multiple affected members. ${ }^{10}$

There is a real need to understand better the relationships between Alzheimer dementia and Down's syndrome and it has been proposed that a further level of their association could be identified in the correspondence of phenotypic particularities observed in Down's syndrome, such as dermatoglyphic patterns. Of the many physical stigma seen in Down's syndrome, characteristic features in dermatoglyphics (configuration of the dermal ridges of palms and palmar creases) have repeatedly been described. ${ }^{1-13}$ Although the genetic mechanisms involved in the determination of dermatoglyphics are obscure, these patterns reflect the influence of multiple additive genetic effects operating in utero, and they remain unaltered throughout an individual's lifespan. Three characteristic patterns are frequently described on Down's syndrome hands: a complete simian crease, cubital palmar loops associated with palmar axial triradius in distal position, and ulnar loops on fingertips.

Some studies on dermatoglyphic patterns ${ }^{14-19}$ have been conducted on Alzheimer patients, suggesting similarities between Alzheimer's disease and Down's syndrome. An excess of digital ulnar loops was first described by Weinreb ${ }^{14}$ on a sample of 50 Alzheimer patients, and by Barclay ${ }^{16}$ on 12 patients. In a study by Seltzer and Sherwin, ${ }^{17}$ men with early onset Alzheimer dementia ( $n=47$, mean age 56.3 years) but not those with late onset ( $n=35,72.7$ years) had significantly more ulnar loops than the conrol group. In two further studies, by Okra-Podrabinek et al ${ }^{18}$ on 34 female Alzheimer patients, and Luxenberg et al ${ }^{19}$ on 56 patients, differences in fingerprint pattern frequencies were also shown. Only three studies have examined palmar configurations. ${ }^{15} 1819$ In the study of Weinreb, ${ }^{15}$ bilateral simian creases 
appeared to be significantly more prevalent in Alzheimer dementia cases $(11 \%)$ than in controls $(4 \%)$. This increase has not, however, been confirmed by others. Moreover, Weinreb ${ }^{15}$ was the only one to report an excess of palmar hypothenar patterns in Alzheimer patients, while OkraPodrabinek et $a l^{18}$ were the only investigators to find a higher transversality index value in Alzheimer patients. A combined analysis of right and left hands was used by Luxenberg et al. ${ }^{19}$ Although this study artificially increased the power of the analysis, it failed to show any differences between Alzheimer patients and controls.

These conflicting results are too scattered to support any hypothesis on a relationship between the two pathologies. Only one study ${ }^{17}$ used evaluations blind to the diagnosis even though these are difficult and can be influenced by the subjectivity of the examiner. We therefore designed a study on a larger sample to compare digital and palmar dermatoglyphics of subjects diagnosed as probable Alzheimer cases with a mentally healthy control group, using an evaluation blind to the diagnosis.

\section{Methods}

POPULATION

Female subjects were recruited from different geriatric units and retirement communities in the Paris area. Because of the highly significant racial differences in dermatoglyphics, ${ }^{13}$ only Europeans were included in both the patient and control groups.

Alzheimer dementia cases-All women patients with Alzheimer type dementia were recruited from geriatric units. There was no age limit for

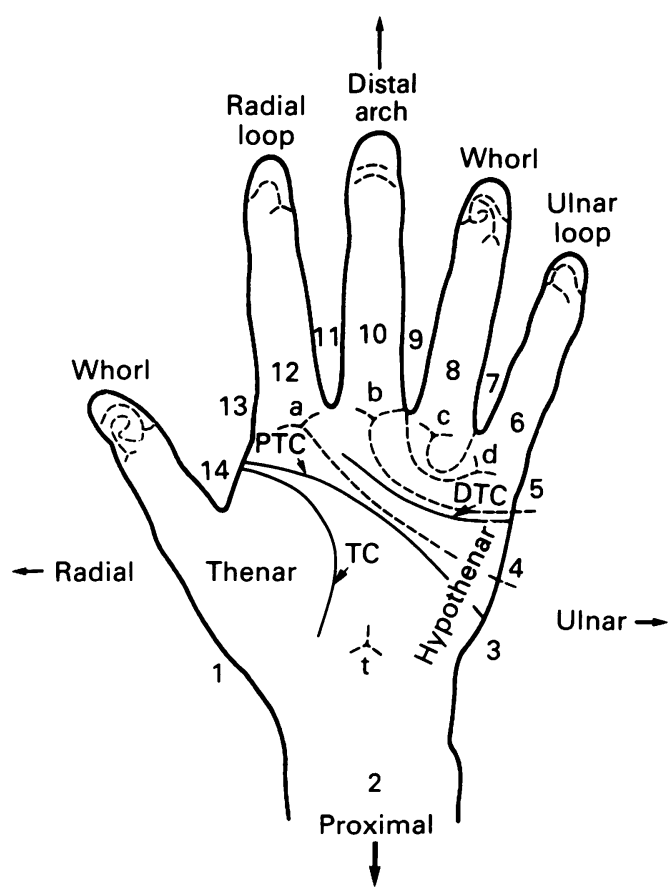

Figure 1 Example in a normal subject. Diagram of palm showing areas, triradii, and main line exit numbers.

Nomenclature of finger pattern types is also indicated.

\begin{tabular}{|l|}
\hline-- Dermal ridges \\
- Palmar creases \\
DTC $=$ Distal transverse crease \\
PTC $=$ Proximal transverse crease \\
TC $=$ Thenar crease \\
Index of $=4+5+9+7=25$ \\
transversality
\end{tabular}

inclusion. Diagnosis was made in agreement with DSM-IIIR criteria for dementia ${ }^{20}$ and the NINCDS-ADRDA criteria for probable Alzheimer's disease. ${ }^{21}$ Other causes of dementia were excluded by a complete clinical and neurological examination, routine biological tests, and a computerised tomography (CT) examination. The level of cognitive deterioration was assessed by the mini-mental state examination (MMSE) ${ }^{22}$ performed within three months of inclusion in the study. MMSE ranged from 0 in subjects with severe mental deterioration to 30 in normal individuals. Age at onset of dementia (earliest manifestations of cognitive changes reported) was based on data from medical and family records.

Controls-We only included controls who were 85 years of age or older. This lower age limit was advocated in order to minimise the inclusion of controls likely to develop a dementing illness later on. Women were mostly recruited in retirement communities. They were eligible if they had no history of memory complaints or cognitive deterioration reported by family members or care givers. A value greater than 23 in MMSE was required at the time of examination.

\section{DERMATOGLYPHIC EXAMINATION}

Finger and palm prints were obtained from both hands, using the standard ink method. The inked hand was pressed on a thin sheet of paper supported by a pad to allow full printing of concavities. Evaluation and classification of the different features were performed independently by two examiners (CB and NOP) who did not know the subject's diagnosis category. Both were similarly trained in interpretation of dermatoglyphics.

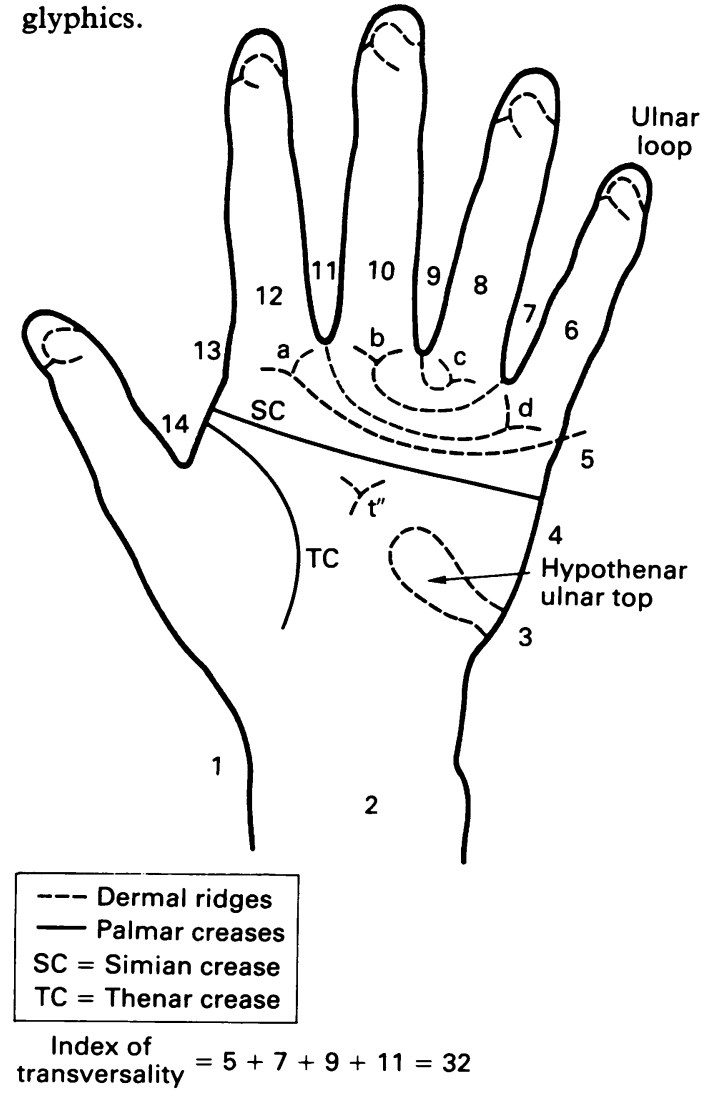

Figure 2 Example in a subject with Down's syndrome. Diagram of palm showing simian crease and high index of transversality. 
The different features presented on figs 1 and 2 were studied on palms and fingers.

Palms-On the palms, two major palmar flexion creases were described: the proximal and distal transverse creases. When those two major palmar flexion creases are replaced by, or joined into, one single crease that traverses the entire palm, a simian crease and its variants (also called a single transverse crease) are described. ${ }^{13}$ Single transverse creases and their variants are observed in $30-60 \%$ of hands of persons with Down's syndrome compared to $1-8 \%$ of controls. ${ }^{1323}$ The Sydney line is the extension of the proximal transverse crease beyond the hypothenar eminence to the ulnar margin of the palm. ${ }^{24}$ The Sydney line, in its complete form or variants, is described in $8 \%$ of the general female population compared to $21 \%$ for female Downs's syndrome cases. $^{24}$

Hypothenar area-In the hypothenar area, true patterns were described. Configurations were classified into loops and combined patterns including whorls. ${ }^{13}$ Loops are further designated as radial, ulnar, or carpal in relation to the aspect of the palm towards which they open. Hypothenar configurations are described in $25-35 \%$ of normal subjects, with mostly radial loops. ${ }^{13}$ Cubital loops are frequent in Down's syndrome, and are described in $55-79 \%$ of hands in affected individuals. ${ }^{13}$

Palmar axial triradii-Palmar axial triradii (a triradius is formed by the confluence of three ridge systems) were described in relation to their orientation and proximal-distal position on the palm; a proximal position is where this triradius tends to have the form of a $\lambda$ (designated by a symbol $t$ ), a distal position is when it lies near the centre of the palm, where it resembles a $\gamma\left(t^{\prime \prime}\right)$, the intermediate position between $t$ and $t^{\prime \prime}\left(t^{\prime}\right)$, and the extralimital border or cubital triradius $\left(t^{b}\right) \cdot{ }^{25}$ In the general population, there is an axial triradius in the proximal or intermediate position in nearly $95 \%$ of all hands. A distally displaced axial triradius $t^{\prime \prime}$, frequently associated with a hypothenar pattern, is present in nearly $70 \%$ of Down's syndrome hands. ${ }^{12}$

Main line terminations-In the distal portion of the palm at the base of digits I, II, III and IV, there are four digital triradii. From each digital triradius emanate main lines, which indicate the generalised ridge direction over the palm, either transverse or longitudinal. These lines are indicated by the capital letters A, B, C, and D. Their terminations are assigned numbers distributed along the periphery of the palm in order to convey information about their course (see figs 1 and 2). The value of the index of transversality (or total main line formula) is conventionally defined by the sum of the exit numbers of the main lines extending from the four digital triradii. ${ }^{12} 26$ If this sum has a low value, say around 21 , this indicates that the alignment tends to be vertical. On the other hand, if the sum is greater than or equal to 31 , this indicates that the alignment tends to be transverse. This value is equal to or greater than 31 in $20 \%$ of controls and $75 \%$ of Down's syndrome subjects. ${ }^{12}$ Right hands generally have higher scores than left hands.

Fingerprints-Fingerprint patterns were classified into plain and tended arches, central pocket loops, and ulnar or cubital loops. ${ }^{13}$ A marked increase in ulnar loops on the fingertips is virtually a constant feature of the dermatoglyphics in Down's syndrome- $75-80 \%$ of all fingertip patterns compared to $60 \%$ in controls. ${ }^{13}$

\section{ANALYSIS}

Interobserver agreement for dermatoglyphic description

The identification and classification of patterns can be hindered by technical problems. These problems are particulary acute with old people whose wrinkled hands require several prints, which even then are not always sufficient to allow complete examination. Description can also be influenced by the subjectivity of the examiner. We therefore studied inter-rater reliability. This was evaluated first by the overall proportion of agreement, which is the proportion of subjects for whom the two examiners agreed in classification. Secondly, we calculated the kappa $(x)$ value, which is a measurement taking into account the fact that some degree of agreement can be expected by chance alone. ${ }^{27}$

\section{Statistical analysis}

Dermatoglyphic patterns were analysed separately for right and left hands and for the presence of a sign on at least one hand. For fingerprint patterns, results are presented for each finger separately. Frequencies of dermatoglyphic patterns were compared between the two groups using the contigency $\chi^{2}$ test or the Fisher exact probability test.

\section{Results}

INTEROBSERVER AGREEMENT (table I)

Due to the poor quality of prints obtained from elderly subjects, 20 right hands and 22 left hands of the 158 subjects examined could not be inter-

Table I Interobserver agreement for characterisation of some dermatoglyphic features.

\begin{tabular}{|c|c|c|c|}
\hline Feature & & $\begin{array}{l}\text { Right } \\
\text { hand }\end{array}$ & $\begin{array}{l}\text { Left } \\
\text { hand }\end{array}$ \\
\hline $\begin{array}{l}\text { Palmar creases } \\
\text { Simian crease } \\
\text { Sydney line } \\
\text { Number of hands evalu }\end{array}$ & $\begin{array}{l}x \text { value } \\
\% \text { agreement } \\
x \text { value } \\
o \text { agreement } \\
\text { ated }^{\mathrm{a}}\end{array}$ & $\begin{array}{l}0.52 \\
92 \% \\
0 \cdot 60^{\circ} \\
96^{\circ} \% \\
138\end{array}$ & $\begin{array}{l}0.37 \\
93^{\circ} \\
0.55^{\circ} \\
96^{\circ} \circ \\
136^{\circ}\end{array}$ \\
\hline $\begin{array}{l}\text { Palmar ridges } \\
\text { Hypothenar patterns } \\
\text { (absent or identified) } \\
\text { Localisation of axial } \\
\text { triradii } \\
\text { Number of hands evalu }\end{array}$ & $\begin{array}{l}x \text { value } \\
\% \text { agreement } \\
x \text { value } \\
\% \text { agreement } \\
\text { ated }^{\mathrm{a}}\end{array}$ & $\begin{array}{l}0 \cdot 74 \\
88^{\circ} \% \\
0 \cdot 76 \\
88^{\circ} \% \\
124\end{array}$ & $\begin{array}{l}0 \cdot 78 \\
88^{\circ} \% \\
0 \cdot 74 \\
86^{\circ} \% \\
140^{\circ}\end{array}$ \\
\hline
\end{tabular}

${ }^{a}$ Hands with patterns evaluated by the two examiners. $\%$ agreement $=$ percentage of overall agreement. Signification of $x$ value: $x>0.75$ excellent agreement; $0.75<x<0.4$ fair to good agreement; $x<0.4$ poor agreement

preted by both examiners for identification of palmar creases. There was a fair concordance for identification of palmar creases $(x$ values ranging between 0.37 and 0.60 ). For ridges, readings by the two examiners were not possible for 34 right hands and 18 left hands. The presence of hypothenar patterns and localisation of main axial triradii were characterised with good agreement beyond chance ( $x$ values between 0.74 and 0.78 ).

In case of discordance, the two examiners re-evaluated prints together in order to obtain a 
consensus. If no consensus was obtained for a given pattern, this pattern, but not the patient, was excluded from the analysis. The data presented result from the combination of the findings of the two examiners.

\section{POPULATION CHARACTERISTICS}

Dermatoglyphic patterns were available on at least one hand for 82 Alzheimer cases and 76 controls. Due to inclusion criteria, the mean age of controls was 89.8 (SD 4.3) years (range 85-104), significantly higher than the mean age of the cases of $81 \cdot 1(7 \cdot 2)$ years (range 60-93). MMSE scores ranged from 0 to 17, mean 7.1(5.3) for Alzheimer cases and from 23 to 30 , mean $26.4(2.2)$ in controls. Age at onset was below 60 years for seven subjects.

\section{ANALYSIS OF DERMATOGLYPHIC PATTERNS \\ Palmar creases (table II)}

The frequency of the simian crease and its variants was slightly but not significantly higher in the Alzheimer group than in the controls. No difference was found for the frequency of the Sydney line.

Hypothenar patterns and axial triradii (table II) Hypothenar patterns were present on the right hand in $41 \%$ of the Alzheimer patients and in $30 \%$ of the controls, and on the left hand in $40 \%$ in both groups. Ulnar loop frequency was low and similar in the two groups. Likewise, axial triradii were quite similarly located in the two groups. The only significant difference found was in the frequency of the extralimital border triradii $\left(t^{b}\right)$ in the right hands of $36 \%$ of the Alzheimer patients compared to $17 \%$ of the controls.

Table II Summary of palmar dermatoglyphics in dementia of Alzheimer type (DAT) patients and controls $(C):$ palmar creases, hypothenar patterns and axial triradii, and index of transversality.

\begin{tabular}{|c|c|c|c|c|c|c|}
\hline & \multicolumn{2}{|c|}{ Right hand } & \multicolumn{2}{|c|}{ Left hand } & \multicolumn{2}{|c|}{ At least one hand } \\
\hline & $D A T$ & $C$ & $\overline{D A T}$ & $C$ & $D A T$ & $C$ \\
\hline $\begin{array}{l}\text { Palmar creases } \\
\text { Number of hands evaluated } \\
\text { Simian crease and its variants } \\
\text { Sydney line and its variants }\end{array}$ & $\begin{array}{l}79 \\
13 \\
(16 \%) \\
4 \\
(5 \%)\end{array}$ & $\begin{array}{l}73 \\
6 \\
(8 \%) \\
11 \\
(15 \%)\end{array}$ & $\begin{array}{l}81 \\
8 \\
(10 \%) \\
9 \\
(11 \%)\end{array}$ & $\begin{array}{l}75 \\
2 \\
(3 \%) \\
8 \\
(11 \%)\end{array}$ & $\begin{array}{l}82 \\
17 \\
(21 \%) \\
12 \\
(15 \%)\end{array}$ & $\begin{array}{l}76 \\
8 \\
(11 \%) \\
17 \\
(22 \%)\end{array}$ \\
\hline $\begin{array}{l}\text { Hypothenar patterns } \\
\text { Number of hands evaluated } \\
\text { No pattern } \\
\text { Ulnar loop } \\
\text { Radial loop } \\
\text { Carpal loop } \\
\text { Complex pattern }\end{array}$ & $\begin{array}{l}81 \\
48 \\
(59 \%) \\
7 \\
(9 \%) \\
17 \\
(21 \%) \\
2 \\
(2 \%) \\
7 \\
(9 \%)\end{array}$ & $\begin{array}{l}70 \\
49 \\
(70 \%) \\
9 \\
(13 \%) \\
9 \\
(13 \%) \\
1 \\
(1 \%) \\
2 \\
(3 \%)\end{array}$ & $\begin{array}{l}80 \\
48 \\
(60 \%) \\
9 \\
(11 \%) \\
18 \\
(22 \%) \\
- \\
- \\
5 \\
(6 \%)\end{array}$ & $\begin{array}{l}72 \\
43 \\
(60 \%) \\
7 \\
(10 \%) \\
14 \\
(19 \%) \\
1 \\
(1 \%) \\
7 \\
(10 \%)\end{array}$ & $\begin{array}{l}82 \\
35 \\
(43 \%) \\
14 \\
(17 \%) \\
27 \\
(33 \%) \\
2 \\
(2 \%) \\
10 \\
(12 \%)\end{array}$ & $\begin{array}{l}76 \\
40 \\
(53 \%) \\
13 \\
(17 \%) \\
17 \\
(22 \%) \\
1 \\
(1 \%) \\
8 \%) \\
(11 \%)\end{array}$ \\
\hline $\begin{array}{l}\text { Axial triradii }{ }^{\mathrm{a}} \\
\text { Number of hands evaluated } \\
\text { Triradii } \mathrm{t} \\
\text { Triradii } \mathrm{t}^{\prime} \\
\text { Triradii } \mathrm{t}^{\prime \prime} \\
\text { Triradii } \mathrm{t}^{\mathrm{b}}\end{array}$ & $\begin{array}{l}81 \\
73 \\
(90 \%) \\
4 \\
(5 \%) \\
15 \\
(19 \%) \\
29 \\
(36 \%)\end{array}$ & $\begin{array}{l}72 \\
67 \\
(93 \%) \\
7 \\
(10 \%) \\
7 \\
(10 \%) \\
12 \\
(17 \%) \dagger\end{array}$ & $\begin{array}{l}81 \\
77 \\
(95 \%) \\
7 \\
(9 \%) \\
12 \\
(15 \%) \\
21 \\
(26 \%)\end{array}$ & $\begin{array}{l}73 \\
69 \\
(95 \%) \\
6 \\
(8 \%) \\
10 \\
(14 \%) \\
22 \%) \\
(30 \%)\end{array}$ & $\begin{array}{l}82 \\
81 \\
(99 \%) \\
11 \\
(13 \%) \\
22 \\
(27 \%) \\
33 \\
(40 \%)\end{array}$ & $\begin{array}{l}76 \\
74 \\
(97 \%) \\
12 \\
(16 \%) \\
13 \\
(17 \%) \\
24 \\
(32 \%)\end{array}$ \\
\hline $\begin{array}{l}\text { Transversality } \\
\text { Number of hands evaluated } \\
\text { Frequency of index of transversality } \geqslant 31\end{array}$ & $\begin{array}{l}76 \\
36 \\
(47 \%)\end{array}$ & $\begin{array}{l}61 \\
28 \\
(46 \%)\end{array}$ & $\begin{array}{l}73 \\
17 \\
(23 \%)\end{array}$ & $\begin{array}{l}64 \\
15 \\
(23 \%)\end{array}$ & & \\
\hline
\end{tabular}

Terminations of the main lines

(detailed data available on request)

Expected differences between right and left hands were observed in the two groups. Right hands had a higher value for the index of transversality. No differences were found between Alzheimer patients and controls for any termination of main lines considered (A, B, C, or D), and general ridge directions were similar.

Fingerprints (table III).

We did not find any differences in frequency for the different features which are usually described for fingertips. Examination of fingertips was more difficult for very old people, resulting in a smaller number of descriptions in the control group, particularly for digit $\mathrm{V}$.

For each of these four features, there was no particular tendency towards bilateral symmetry, as observed in Down's syndrome hands. There was no difference in dermatoglyphic configurations between Alzheimer patients with early onset of dementia (seven subjects with onset prior to 60 years), and other Alzheimer patients and controls.

Table III Percent of ulnar loops and whorls in individual fingertips in dementia of Alzheimer type $(D A T)$ patients and controls $(C)$.

\begin{tabular}{|c|c|c|c|c|}
\hline & \multicolumn{2}{|c|}{ Right hand } & \multicolumn{2}{|c|}{ Left hand } \\
\hline & $\overline{D A T}$ & $C$ & $D A T$ & $C$ \\
\hline $\begin{array}{l}\text { Digit I } \\
\text { Ulnar loops } \\
\text { Whorls } \\
\text { Digit II } \\
\text { Ulnar loops } \\
\text { Whorls } \\
\text { Digit III } \\
\text { Ulnar loops } \\
\text { Whorls } \\
\text { Digit IV } \\
\text { Ulnar loops } \\
\text { Whorls } \\
\text { Digit V } \\
\text { Ulnar loops } \\
\text { Whorls }\end{array}$ & $\begin{array}{l}(\mathrm{n}=77) \\
61 \% \\
36 \% \\
(\mathrm{n}=74) \\
41 \% \\
36 \% \\
(\mathrm{n}=79) \\
84 \% \\
13 \% \\
(\mathrm{n}=76) \\
50 \% \\
41 \% \\
(\mathrm{n}=69) \\
77 \% \\
20 \%\end{array}$ & $\begin{array}{l}(n=68) \\
66 \% \\
29 \% \\
(n=64) \\
42 \% \\
34 \% \\
(n=67) \\
81 \% \\
13 \% \\
(n=65) \\
55 \% \\
35 \% \\
(n=58) \\
79 \% \\
14 \%\end{array}$ & $\begin{array}{l}(\mathrm{n}=80) \\
56 \% \\
35 \% \\
(\mathrm{n}=75) \\
37 \% \\
43 \% \% \\
(\mathrm{n}=76) \\
63 \% \\
20 \% \\
(\mathrm{n}=76) \\
59 \% \\
33 \% \\
(\mathrm{n}=68) \\
81 \% \\
18 \%\end{array}$ & $\begin{array}{l}(n=62) \\
611^{\circ} \\
34^{\circ} \% \\
(n=59) \\
29 \% \\
31^{\circ} \% \\
(n=64) \\
66^{\circ} \% \\
20^{\circ} \% \\
(n=65) \\
54^{\circ} \% \\
35^{\circ} \% \\
(n=57) \\
74^{\circ} \% \\
21^{\circ} \%\end{array}$ \\
\hline
\end{tabular}

\section{Discussion}

Although this study was performed on a sample larger than previously published studies, with dermatoglyphic evaluation blind to diagnosis, we did not find significant differences in dermatoglyphic features between female Alzheimer patients, mostly with dementia onset after 60 years, and elderly female controls. Discrepancies with previous studies ${ }^{14-19}$ may be explained by differences in methods and in the definition of the control group.

There are several recommended nomenclatures for dermatoglyphic patterns. In this study, we tried to adopt "accepted" criteria as described in Methods. It is unlikely that differences in pattern classification could explain discrepancies between results. Strong classification bias could appear if there is variability or subjectivity in the evaluation of dermatoglyphics. One of the best ways to minimise this bias is to perform evaluation blind to the clinical diagnosis, as we did in this study. Futhermore, we examined interobserver agreement and the fairly good quality of agreement led us to perform double readings in all cases and to 
retain only those descriptions obtained by consensus.

Moreover, this work differs from previous studies in the definition of the control group. Classically, controls are matched with cases for age and sex. We tried to reduce the problem of misclassification of subjects by selecting controls at an age when most Alzheimer dementia cases are already declared. Thus we were more likely to detect differences, if any did exist, between Alzheimer cases and very elderly controls than between cases and age matched controls. This choice was possible because there are no grounds for believing that dermatoglyphics are affected by longevity ( $\mathrm{N}$ Okra-Podrabinek, data to be published).

Although we have studied one of the largest samples in the literature, it is possible that this study may not be powerful enough to detect slight differences, especially if they are attributable to a subgroup of "genetic" Alzheimer's disease. Many studies provide evidence supporting the heterogeneity of Alzheimer cases. ${ }^{28} 29$ Sporadic cases and inherited forms of the disease coexist but are not always distinguishable, due to incomplete family reports. Ascertainment of pedigrees with multiple affected individuals argues in favour of the existence of a familial form of the disease in more than 50 families with an apparent autosomal dominant pattern of inheritance. ${ }^{30}$ Most of these familial forms, which are rare, had an early age of onset, defined as prior to 60 years. ${ }^{31}$. Only seven cases with early onset of dementia were included in our study. This subgroup did not differ from the other patients with dementia onset after 60 years old.

No significant differences were observed between Alzheimer patients and controls, but it is disconcerting that there was a slight increase in frequency in the dementia group of two of the three signs which are linked to Down's syndrome $^{12}$ : simian crease and distal axial triradius. The small number of subjects did not allow us to draw any conclusions with respect to early onset dementia. If the hypothesis of different aetiological mechanisms between late and early onset cases is maintained, then our conclusion must be restricted to late onset Alzheimer cases.

We are grateful to the personnel of the retirement communities for their help in recruiting the control group: Fondation Cousin de Méricourt, Cachan (Dr Flouzat), Foyer-Logement Fer à Moulin, Cachan (Mme Masson), Hopital Corentin-Celton, Issy-LesMoulineaux (Dr Delcros). We also wish to thank Marguerite Prieur for her kind and helpful counsel with our dermatoglyphic analysis. This work was support in part by a grant from the IPSEN Foundation (Paris).
1 Katzman R. Alzheimer's disease. Trends Neurosci 1986; 9: $522-5$.

2 Henderson AS. Epidemiology of dementia disorders. $A d v$ Neurol 1990; 51: 15-25.

3 Katzman R, Saitoh T. Advances in Alzheimer's disease. FASEB f 1991; 5: 278-86.

4 Kay DWK. Genetics, Alzheimer's disease and senile dementia. Br F Psychiatry 1989; 154: 311-20.

5 Whalley LJ. The dementia of Down's syndrome and its relevance to aetiological studies of Alzheimer's disease. Ann NY Acad Sci 1982; 396: 39-53.

6 Thase ME, Tigner R, Smeltzer DJ, Liss L. Age-related neuropsychological deficits syndrome. Biol Psychiatry 1984; 19: 571-85.

7 Wisniewski KE, Wisniewski HM, Wen G. Occurrence of neuropathological changes and dementia of Alzheimer's disease in Down syndrome. Ann Neurol 1985; 17; 278-82.

8 Lot IT Down's syndrome aing and Alzheimer's disease: a clinical review. Ann NY Acad Sci 1982; 396: 15-27.

9 Goate A, Chartier-Harlin MC, Mullan M, Brown J, Crawford F, Fidani L. Segregation of a missense mutation in the amyloid precusor protein gene with familial in the amyloid precusor protein gene with

10 St George-Hyslop PH, Hines JL, Farrer LA, et al. Genetic linkage studies suggest that Alzheimer's disease is not a single homogeneous disorder. Nature 1990; 347: 194-7.

11 Penrose LS. Familial studies in palmar patterns in relation to mongolism. Proc Eighth Int Cong Genet London. Hereditas 1949; suppl: 412-6.

12 Turpin R, Lejeune J. Etude dermatoglyphique des paumes des mongoliens et de leurs parents et germains. Semain Hôp Paris 1953; 29: 3955-67.

13 Schaumann B, Alter M. Dermatoglyphics in medical disorders. New York: Springer Verlag, 1976

14 Weinreb HJ. Fingerprint patterns in Alzheimer's disease. Arch Neurol 1985; 42: 50-4.

15 Weinreb HJ. Dermatoglyphic patterns in Alzheimer's disease. $₹$ Neurogenet 1986; 3: 233-46.

16 Barclay L. Genetics in Alzheimer's disease: methodological problems, research strategies, and practical applications. problems, research strategies, and
Neurobiol Aging 1986; 7: 479-80.

17 Seltzer B, Sherwin I. Fingerprint pattern differences in early- and late-onset primary degenerative dementia. Arch Neurol 1986; 43: 665-8.

18 Okra-Podrabinek N, Roudier M, Lamour Y, De Grouchy J. Dermatoglyphic patterns in senile dementia of Alzheimer's type. Ann Genet 1988; 31: 91-6.

19 Luxenberg JS, Plato CC, Fox KM, Freidland RP, Rapoport SI. Digital and palmar dermatoglyphics in dementia of the Alzheimer type. Am $\mathcal{f}$ Med Genet 1988; 30: 733-40.

20 American Psychiatric Association. Diagnostic and statistical manual of mental disorders (third edition revised) Washingtom DC, 1987 .

21 McKhann G, Drachman D, Folstein M, et al. Clinical diagnosis of Alzheimer's disease: report of the NINCDSdiagnosis of Alzheimer's disease: report of the NINCDSADRDA work group under the auspices of Department of
Health and Human Services task force of Alzheimer's disease. Neurology 1984; 34: 939-44.

22 Folstein M, Folstein S, McHugh PR. Mini-mental state: a practical method for grading the cognitive state of patients for the clinician. F Psychiatr Res 1975; 12: 189-98.

23 Turpin R, Schutzenberger MP. L'étude des dermatoglyphes. Semain Hôp Paris 1949; 29: 2553-62.

24 Purvis-Smith SG. The Sydney line: a significant sign in Down's syndrome. Aust Paediatr $\mathcal{F}$ 1972; 8: 198.

25 Penrose LS. Memorandum on dermatoglyphic nomenclature. Birth Defects Original Articles Series 1968; 4 $1-13$.

26 Cummins H, Midlo C. Fingerprints, palms and soles. Philadelphia: Blakinston, 1943.

27 Fleiss JL. The measurement of interrater agreement. In: Statistical methods for rates and proportions, ch 13. New York: John Wiley and sons, 1981 .

28 Kay DWK. Heterogeneity in Alzheimer's disease, Kay DWK. Heterogeneity in Alzheimer's disease,
epidemiological and family studies. Trends Neurosci 1987; epidemiolo $194-5$.

29 Edwards JK, Larson EB, Hughes JP, Kukull WA. Are there clinical and epidemiological differences between familial and non-familial Alzheimer's disease. $\mathcal{F} \mathrm{Am}$ Geriatr So 1991; 39: 477-83

30 Cook R, Ward B, Austin J. Studies in aging of the brain. IV. Familial Alzheimer disease; relation to transmissible dementia, aneuploidy and microtubular defects. Neurology 1979; 29: 1402-12.

31 Chui EC. The significance of clinically defined subgroups of Alzheimer's disease. F Neural Transm Suppl 1987; 24: 57-68. 